\title{
Response to Asa Kasher and Amos Yadlin
}

\author{
Michael Walzer ${ }^{1}$
}

Received: 22 October 2015 / Accepted: 22 April 2016/

Published online: 29 July 2016

(C) Springer Science+Business Media Dordrecht 2016

This is a very long response to the short article that I wrote some years ago, and I am not able, given the pressure of my own commitments, to respond in a similarly lengthy way. I appreciate the care with which Asa Kasher and Amos Yadlin have constructed their argument, but I shall have to confine myself to a few pointed comments.

1. The analogy to Afghanistan is indeed imperfect, like all analogies, though I think that it is considerably less imperfect than Kasher and Yadlin suggest. One small correction, which is, however, central to their larger argument: it is not right to say that the Afghan government had "effective control" over most of the areas where American soldiers were fighting. Would that it were true, but it was precisely "control" that was at issue in the fighting. I am more interested, however, in the diligence with which Kasher and Yadlin describe the differences between Israel in Gaza and the US in Afghanistan. For what they have done is to construct a picture of the situation of Israeli soldiers in Gaza that is not only radically dissimilar to that of US soldiers in Afghanistan; it is, I think, unique in the world. At least, I cannot think of other examples. It follows, then, that insofar as the situation in Gaza requires specific moral arguments, these are arguments that can be made only on behalf of Israeli soldiers. This is a claim that seems to me both morally dubious and politically dangerous.

(A parenthetical note: It was American officers who had recently returned from Afghanistan who first suggested the Afghanistan-Gaza analogy to me, and when they did that they were obviously identifying with and sympathizing with their Israeli counterparts. I would not be too quick to tell them that they were wrong.)

2. I think that what Kasher and Yadlin mean by "justified risk" is any risk that is militarily required-required, that is, by the military mission. And what they mean by "excessive risk" is any additional risk that (on my view) might be

Michael Walzer

walzer@ias.edu

1 School of Social Science, Institute of Advanced Study, Princeton, NJ, USA 
morally required. With regard to this possible addition, their position is precisely "zero"- no additional risk can be required, at least not from Israeli soldiers fighting under the conditions they describe in Gaza. Moral principles cannot justify any risks beyond those that are produced by the actual military situation. That seems to me the Kasher/Yadlin "official" position. And the firmness with which they state that position, and illustrate it with their third example (about terrorists in a building along with civilians), highlights our disagreement.

3. But is that actually their position? I may be wrong, but I sense some wavering from their own "official" line. First of all, they say that even when the policy of warning civilians might have military costs (they don't say "risks," but that's what costs usually mean), even then, Israel should deliver the warnings. The IDF should make the effort to reduce collateral damage "beyond that required by the principle of proportionality." Second, though they usually don't want to go "beyond" the principle of proportionality, they do consistently uphold it. That means that soldiers must attack their target in ways that do not cause disproportionate injury to civilians. But there will be many instances where this principle will rule out less risky attacks and require soldiers to take the additional risks that proportionality enjoins. If Kasher and Yadlin choose to deny this, and insist that all additional risks are "excessive," then they have given up proportionality as an effective constraint on the conduct of war. But if they don't deny it, then they are stuck with the "some risk" position that I tried to defend and that provides, as they rightly say, no precise guidance.

4. But it isn't right to expect philosophers and political theorists to provide precise guidance. It would be inexcusably presumptuous for us to try to do that while we are sitting in our academic offices. All we can do is to argue for the moral principles and military considerations that officers in the field have to think about when making the critical decisions they can't avoid. "Some risk" is the best guidance we can provide. It means that the officers have to ask whether there are ways of carrying out their mission that might reduce civilian casualties. And if there are such ways, they have to weigh the risks involved to their own men: do those risks fall within an acceptable range? If Kasher and Yadlin believe in giving warnings and if they accept the proportionality constraint, then they must agree that there is an acceptable range - even if they can't give a precise account of it, any more than I can.

5. Their list of "dangers that soldiers are exposed to and civilians are not" is impressive, but it has to be set alongside the numbers of civilians and soldiers actually killed or injured in recent wars - say, all the wars from Korea and Vietnam to Afghanistan and Gaza. I am afraid that however great the dangers that soldiers face, the dangers that civilians face are far greater. Contemporary warfare is mostly a disaster for civilians. I entirely agree that when terrorists hide among the civilian population, they bear primary responsibility for the disaster. But primary responsibility is not sole responsibility. Soldiers confronting terrorists have decisions to make about how to do that. Surely there is a moral imperative to look for ways of reducing the dimensions of the disaster, and unless we accept risk-taking as a possibility, there won't be many options to consider. 
6. The soldiers we are talking about are citizens of democratic states, and their governments do indeed have obligations to them. As Kasher and Yadlin say, these governments have to give reasons for the risks they ask soldiers to accept. Trying to avoid killing innocent men, women, and children is one among the reasons they can rightly give. 